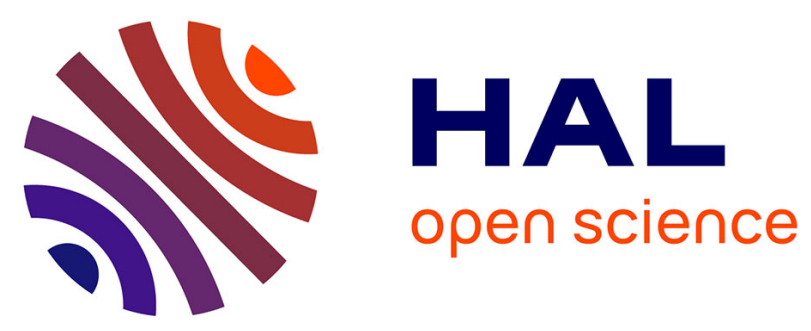

\title{
$\beta$-Galactosidase from Lactobacillus pentosus: Purification, characterization and formation of galacto-oligosaccharides
}

Thomas Maischberger, Elisabeth Leitner, Sunee Nitisinprasert, Onladda Juajun, Montarop Yamabhai, Thu-Ha Nguyen, Dietmar Haltrich

\section{To cite this version:}

Thomas Maischberger, Elisabeth Leitner, Sunee Nitisinprasert, Onladda Juajun, Montarop Yamabhai, et al.. $\beta$-Galactosidase from Lactobacillus pentosus: Purification, characterization and formation of galacto-oligosaccharides. Biotechnology Journal, 2010, 5 (8), pp.838. 10.1002/biot.201000126 . hal00560295

\section{HAL Id: hal-00560295 \\ https://hal.science/hal-00560295}

Submitted on 28 Jan 2011

HAL is a multi-disciplinary open access archive for the deposit and dissemination of scientific research documents, whether they are published or not. The documents may come from teaching and research institutions in France or abroad, or from public or private research centers.
L'archive ouverte pluridisciplinaire HAL, est destinée au dépôt et à la diffusion de documents scientifiques de niveau recherche, publiés ou non, émanant des établissements d'enseignement et de recherche français ou étrangers, des laboratoires publics ou privés. 


\section{$\beta$-Galactosidase from Lactobacillus pentosus: Purification, characterization and formation of galacto-oligosaccharides}

\begin{tabular}{|c|c|}
\hline Journal: & Biotechnology Journal \\
\hline Manuscript ID: & biot.201000126.R2 \\
\hline Wiley - Manuscript type: & Research Article \\
\hline $\begin{array}{r}\text { Date Submitted by the } \\
\text { Author: }\end{array}$ & $02-J u l-2010$ \\
\hline Complete List of Authors: & $\begin{array}{l}\text { Maischberger, Thomas; Food Biotechnology Laboratory, BOKU } \\
\text { University of Natural Resources and Applied Sciences; Research } \\
\text { Centre Applied Biocatalysis } \\
\text { Leitner, Elisabeth; Food Biotechnology Laboratory, BOKU } \\
\text { University of Natural Resources and Applied Sciences } \\
\text { Nitisinprasert, Sunee; Department of Biotechnology, Kasetsart } \\
\text { University } \\
\text { Juajun, Onladda; Food Biotechnology Laboratory, BOKU University } \\
\text { of Natural Resources and Applied Sciences; School of } \\
\text { Biotechnology, Suranaree University of Technology } \\
\text { Yamabhai, Montarop; Suranaree University of Technology, School } \\
\text { of Biotechnology } \\
\text { Nguyen, Thu-Ha; Vienna University of Natural Resources and } \\
\text { Applied Life Sciences, Department of Food Sciences and } \\
\text { Technology, Food Biotechnology Lab } \\
\text { Haltrich, Dietmar; Universität für Bodenkultur, Food Sciences and } \\
\text { Technology }\end{array}$ \\
\hline Primary Keywords: & Food Biotechnology \\
\hline Secondary Keywords: & Enzymes \\
\hline Keywords: & lactase, lactic acid bacteria, transgalactosylation, biocatalaysis \\
\hline
\end{tabular}

\section{S) ScholaroNE" \\ Manuscript Central}


Research Article 6532 words

\title{
$\beta$-Galactosidase from Lactobacillus pentosus: Purification, characterization and formation of galacto-oligosaccharides
}

\author{
THOMAS MAISCHBERGER ${ }^{1,2}$, ELISABETH LEITNER ${ }^{1}$, SUNEE NITISINPRASERT ${ }^{3}$, \\ ONLADDA JUAJUN ${ }^{1,4}$, MONTAROP YAMABHAI ${ }^{4}$, THU-HA NGUYEN $^{1,2, *}$ AND DIETMAR \\ $\mathrm{HALTRICH}^{1}$ \\ ${ }^{1}$ Food Biotechnology Laboratory, BOKU University of Natural Resources and Applied Sciences, \\ Vienna, Austria \\ ${ }^{2}$ Research Centre Applied Biocatalysis, Graz, Austria \\ ${ }^{3}$ Department of Biotechnology, Kasetsart University, Bangkok, Thailand \\ ${ }^{4}$ School of Biotechnology, Suranaree University of Technology, Nakhon Ratchasima, Thailand
}

Keywords: Lactase $\cdot$ Lactic acid bacteria $\cdot$ Transgalactosylation · Biocatalysis

*Correspondence: Dr. Nguyen Thu-Ha (e-mail: thu-ha.nguyen@boku.ac.at). Address: Lebensmittelbiotechnologie, Department für Lebensmittelwissenschaften und technologie, Universität für Bodenkultur Wien, Muthgasse 18, A-1190 Vienna, Austria. Phone: 43-1-47654 6146. Fax: 43-1-47654 6251.

\begin{abstract}
Abbreviations: $\beta$-Gal, $\beta$-galactosidase; CE, capillary electrophoresis; $\mathbf{G O S}$, galactooligosaccharides; HPAEC-PAD, high-performance anion exchange chromatography with pulsed amperometric detection; MUG, 4-methylumbelliferyl- $\beta$-D-galactopyranoside; oNPG, onitrophenyl- $\beta$-D-galactopyranoside, oNP, o-nitrophenol
\end{abstract}




\section{Abstract}

A novel heterodimeric $\beta$-galactosidase with a molecular mass of $105 \mathrm{kDa}$ was purified from the crude cell extracts of the soil isolate Lactobacillus pentosus KUBST10-1 using ammonium sulphate fractionation followed by hydrophobic interaction

5 and affinity chromatography. The electrophoretically homogenous enzyme has a specific activity of $97 \mathrm{U}_{\mathrm{NNPG}} / \mathrm{mg}$ protein. The $\mathrm{K}_{\mathrm{m}}, \mathrm{k}_{\text {cat }}$ and $\mathrm{k}_{\text {cat }} / \mathrm{K}_{\mathrm{m}}$ values for lactose and $\mathrm{oNPG}$ were $38 \mathrm{mM}, 20 \mathrm{~s}^{-1}, 530 \mathrm{M}^{-1} \cdot \mathrm{s}^{-1}$ and $1.67 \mathrm{mM}, 540 \mathrm{~s}^{-1}, 325,000 \mathrm{M}^{-1} \cdot \mathrm{s}^{-1}$, respectively. The temperature optimum of $\beta$-galactosidase activity was $60-65^{\circ} \mathrm{C}$ for a 10-min assay, which is considerably higher than the values reported for other

10 lactobacillal $\beta$-galactosidases. $\mathrm{Mg}^{2+}$ ions enhanced both activity and stability significantly. L. pentosus $\beta$-galactosidase was used for the production of prebiotic galacto-oligosaccharides (GOS) from lactose. A maximum yield of $31 \%$ GOS of total sugars was obtained at $78 \%$ lactose conversion. The enzyme showed a strong preference for the formation of $\beta-(1 \rightarrow 3)$ and $\beta-(1 \rightarrow 6)$ linkages, and the main

15 transgalactosylation products identified were the disaccharides $\beta$-D-Galp- $(1 \rightarrow 6)-\mathrm{D}$ -

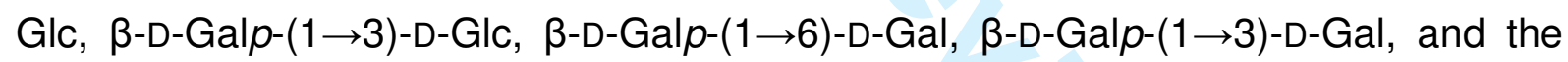

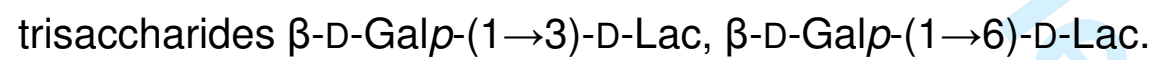




\section{Introduction}

The lactic acid bacterium $L$. pentosus is frequently used as starter culture for silage

20 fermentations and various food fermentation processes, including sauerkraut and raw sausage production, or olive and tea leave fermentations, to name a few. Most of $L$. pentosus subspecies are plant isolates, generally recognised as safe (GRAS), and capable of metabolising different pentoses such as ribose, arabinose and xylose [1]. Yet, some subspecies of $L$. pentosus were isolated from e.g. human faeces [2] or 25 from raw milk [3], which were proposed as potentially probiotic strains. Furthermore, Fred et al. previously described very effective growth of $L$. pentosus on lactose, which could imply high $\beta$-galactosidase activity [4], but this property has not been studied to date.

Lactic acid bacteria ( $L A B)$ and $\beta$-galactosidases have been studied extensively in the

30 past, both from a fundamental and an applied point of view. $\beta$-Galactosidases from e.g. Bifidobacterium bifidum, B. infantis [5], Carnobacterium piscicola [6], L. acidophilus [7], L. bulgaricus [8], L. reuteri [9], and Leuconostoc lactis [10] were cloned and characterised to a varying detail. Despite of the importance of LAB and in particular Lactobacillus spp. for food technology and dairy applications and despite of 35 numerous studies on the gene clusters involved in lactose utilisation, only few lactobacillal $\beta$-galactosidases were characterised in detail pertaining to their biochemical properties or were investigated for their ability to produce galactooligosaccharides (GOS) in biocatalytic processes [11-13]. These carbohydrate-based food ingredients are of interest as novel and possibly improved prebiotics, or for the

40 development of synbiotic functional food that could introduce new dimensions of applications [14].

GOS belong to the prebiotics, which are defined as a "selectively fermented ingredient that allows specific changes, both in the composition and/or activity in the 
gastrointestinal microbiota that confers benefits upon host well-being and health" 45 [15]. In practice, the beneficial bacteria that serve as targets for prebiotics and GOS are almost exclusively bifidobacteria and lactobacilli. An advantage of the concept of prebiotics to modify gut function is that the target bacteria are already commensal to the large intestine, whereas with probiotics allochthonous micro-organisms are introduced and have to compete against established colonic communities [16]. GOS 50 have been classified as one of the few proven prebiotics fulfilling the three criteria (i) resistance to gastric acidity, hydrolysis by mammalian enzymes and gastrointestinal absorption; (ii) fermentation by intestinal microflora; and (iii) selective stimulation of the growth and/or activity of intestinal bacteria associated with health and well-being [15]. GOS have been widely investigated for their prebiotic properties and 55 physiological effects using in vitro, animal, human, and infant studies, and functional effects of GOS on human health are summarised in [16], [20] and [21].

GOS are produced from lactose using $\beta$-galactosidases (E.C. 3.2.1.23), which in addition to their hydrolytic activity catalyse glycosyl transfer reactions. In this reaction galactosyl residues are transferred onto suitable acceptors such as another sugar 60 (lactose, the primary reaction products glucose and galactose, or other oligosaccharides formed), thus building up complex series of higher oligosaccharides [17-19]. The spectrum of the oligosaccharides making up these mixtures strongly depends on the source of the $\beta$-galactosidase used for the biocatalytic reaction, and on the conversion conditions used in their production. Since these differences in 65 GOS spectrum and yields are a result of structural and/or mechanistic differences between $\beta$-galactosidases from different sources, a detailed knowledge on novel, yetunexplored $\beta$-galactosidases from various strains can be of significant interest [18]. Rabiu et al. [22] and Tzortzis et al. [23] synthesised a range of GOS mixtures from lactose using $\beta$-galactosidases from different bifidobacteria. Subsequently it was 
70 shown that these different mixtures typically resulted in better growth of that strain that had served as the source of the enzyme for GOS production. This concept may serve as the basis for a new generation of functionally enhanced, targeted oligosaccharides, and has increased the interest in $\beta$-galactosidases from beneficial probiotic organisms.

75 The objective of this work was to study the $\beta$-galactosidase from $L$. pentosus in detail and to compare it to other lactobacillal $\beta$-galactosidases isolated from organisms of typical animal origin. Recent data are indicating that $L$. pentosus might be of interest as a beneficial $L A B$ making it attractive as a probiotic strain, e.g. based on immunomodulating properties [24] or the reduction of pathogens in animals [25].

80

\section{Material and Methods}

\subsection{Strain and culture conditions}

Lactobacillus pentosus KUB-ST10-1 was from the culture collection of Kasetsart University (Bangkok, Thailand). It was isolated from soil of a dairy farm in Thailand

85 and identified by using both the API $50 \mathrm{CH}$ carbohydrate fermentation stripes test (bioMérieux, Inc., Marcy l'Etoile, France) and sequence analysis of the amplified chromosomal $16 \mathrm{~S}$ rDNA. It was stored at $-70^{\circ} \mathrm{C}$ in MRS broth medium (Merck, Darmstadt, Germany) containing $15 \%$ glycerol. To prepare fresh inocula, it was transferred twice after an 18-h cultivation period to fresh MRS broth medium 90 supplemented with lactose (final concentration of $2 \%$ ).

L. pentosus KUB-ST10-1 was grown anaerobically in $10 \mathrm{~L}$ of MRS broth medium containing $2 \%$ lactose at $37^{\circ} \mathrm{C}$ with slight agitation and without $\mathrm{pH}$ control. A preculture, grown overnight in MRS medium (2\% lactose $(w / v))$, was used to inoculate the fresh medium to a final concentration of $1 \%(\mathrm{v} / \mathrm{v})$ inoculum. Cells were 
95 harvested at an optical density $\left(O D_{600}\right)$ of 13 by centrifugation at $8800 \times g$ for 15 min at $4^{\circ} \mathrm{C}$.

\subsection{Enzyme purification}

$\beta$-Galactosidase was purified from the crude extract using a previously described protocol [9]. Wet biomass (100 g) was resuspended in $200 \mathrm{~mL}$ of sodium phosphate

100 buffer (50 mM, pH 6.5) and homogenized (APV-2000; Silkeborg, Denmark) to disrupt the cells. Cell debris was removed by ultracentrifugation $\left(36000 \times \mathrm{g}, 30 \mathrm{~min}, 4^{\circ} \mathrm{C}\right)$ to obtain the crude enzyme extract.

Ammonium sulphate precipitation (ASP). Ammonium sulphate was added in small portions to the crude extract to a final concentration of $50 \%$ saturation under

105 continuous stirring at $4^{\circ} \mathrm{C}$. The precipitated protein was collected by centrifugation (6200 $\left.\times \mathrm{g}, 15 \mathrm{~min}, 4^{\circ} \mathrm{C}\right)$, and the pellet was re-dissolved in $50 \mathrm{mM}$ sodium phosphate buffer ( $\mathrm{pH}$ 6.5) containing $1 \mathrm{M}$ ammonium sulphate (buffer $\mathrm{A})$.

Hydrophobic Interaction Chromatography (HIC). The dissolved pellet was loaded onto a 20-mL phenyl-sepharose fast flow column $(50 \mathrm{~mm}$ x $200 \mathrm{~mm}$; Amersham,

110 Uppsala, Sweden) that had been pre-equilibrated with buffer A. Proteins were eluted by a linear gradient of $0 \%$ to $100 \%$ buffer B (50 mM sodium phosphate buffer, $\mathrm{pH}$ 6.5) over 10 column volumes $(\mathrm{CV})$ and at a flow rate of $1.5 \mathrm{~mL} / \mathrm{min}$. Fractions with high $\beta$-galactosidase activity were pooled and concentrated by ultrafiltration (30-kDa cut-off; Amicon, Beverly, MA).

115 Affinity Chromatography (AC). The concentrated protein solution was applied to a 5$\mathrm{mL}$ column containing crosslinked $(4 \%)$ beaded agarose immobilized with $p$ aminobenzyl-1-thio- $\beta$-D-galactopyranoside (Sigma, St. Louis, MO) that was preequilibrated with $50 \mathrm{mM}$ phosphate buffer $\mathrm{pH}$ 6.5. The enzyme was eluted using a flow rate of $0.5 \mathrm{~mL} / \mathrm{min}$ and a linear gradient $(0$ to $1 \mathrm{M} \mathrm{NaCl}$ in the same buffer) over 
$12010 \mathrm{CV}$. Active fractions were pooled, desalted and concentrated by ultrafiltration. The purified enzyme was stored in $50 \mathrm{mM}$ sodium phosphate buffer $\left(\mathrm{pH} \mathrm{6.5)}\right.$ at $4^{\circ} \mathrm{C}$.

\subsection{Enzyme assays}

$\beta$-Galactosidase activity was determined using both the artificial chromogenic substrate $o$-nitrophenyl- $\beta$-D-galactopyranoside (oNPG) and the natural substrate

125 lactose as described previously [9]. When oNPG was the substrate, the reaction was performed in $50 \mathrm{mM}$ sodium phosphate buffer ( $\mathrm{pH} \mathrm{6.5)} \mathrm{and} \mathrm{using} \mathrm{a} \mathrm{10-min} \mathrm{incubation}$ at $30^{\circ} \mathrm{C}$, after which the reaction was stopped. One unit of oNPG activity $\left(\mathrm{U}_{o N P G}\right)$ is defined as the amount of enzyme releasing $1 \mu \mathrm{mol}$ of oNP per minute under the assay conditions described above. When lactose was used as the substrate, the

130 reaction was done in $50 \mathrm{mM}$ sodium phosphate buffer $(\mathrm{pH} 6.5)$ for $10 \mathrm{~min}$ at $30^{\circ} \mathrm{C}$, after which the reaction was stopped. The release of D-glucose was determined colourimetrically using the glucose oxidase/peroxidase (GOD/POD) assay [26]. One unit of lactase activity $\left(U_{\text {Lac }}\right)$ is defined as the amount of enzyme releasing $1 \mu \mathrm{mol}$ of D-glucose per minute under the conditions listed above.

\subsection{Protein analysis and gel electrophoresis}

Protein concentrations were determined by the method of Bradford [27] using bovine serum albumin as the standard. The PhastSystem unit (Amersham) and precast polyacrylamide gels (Phastgel 8-25, Amersham) were used for performing native and SDS-PAGE. Samples were treated as described by Laemmli [28] with slight 140 modifications. The enzyme was diluted to $1-2 \mathrm{mg}$ of protein per $\mathrm{mL}$ and incubated with $2 \mathrm{x}$ Laemmli buffer at $60^{\circ} \mathrm{C}$ for $5 \mathrm{~min}$. Protein bands were stained using either Coomassie Blue staining or 4-methylumbelliferyl- $\beta$-D-galactopyranoside (MUG) as substrate for active staining. For SDS-PAGE and native PAGE molecular masses 
were estimated using the Precision Plus Protein Dual Color Kit (Biorad) and the High

145 Molecular Weight calibration Kit (Amersham), respectively.

\subsection{Steady-state kinetic measurement}

Catalytic constants were determined at $30^{\circ} \mathrm{C}$ and $\mathrm{pH} 6.5$ for the two substrates oNPG and lactose with their concentrations in $50 \mathrm{mM}$ phosphate buffer varying from $0.1-22$ $\mathrm{mM}$ and $0.1-600 \mathrm{mM}$, respectively. The kinetic parameters were calculated by non-

150 linear regression, and the obtained data were fit to the Henri-Michaelis-Menten equation (using SigmaPlot, SPSS Inc., Chicago, IL, USA).

\subsection{Effects of temperature and pH on enzyme activity and stability}

The temperature dependence of $\beta$-galactosidase activity (both oNPG and lactose) was determined by assaying the enzyme samples over the range of 20 to $70^{\circ} \mathrm{C}$ for 10

155 min. To study thermal stability, enzyme samples were incubated in $50 \mathrm{mM}$ sodium phosphate buffer, $\mathrm{pH} 6.5$, at $4,23,30,37$, and $42^{\circ} \mathrm{C}$. At certain time intervals samples were taken and the residual oNPG activity was measured. For measuring the $\mathrm{pH}$ dependence of $\beta$-galactosidase activity three buffer systems (sodium citrate, $50 \mathrm{mM}$, pH 4.0-5.5; sodium phosphate, 50 mM, pH 5.5-7.5; glycine, 50 mM, pH 7.5-

160 9.0) were used. For the determination of the $\mathrm{pH}$ stability enzyme samples were incubated at various $\mathrm{pH}$ values and $37^{\circ} \mathrm{C}$ for up to $72 \mathrm{~h}$, and the remaining enzyme activity was measured at certain time intervals using oNPG as substrate under standard assay conditions.

\subsection{Substrate specificity}

165 To determine the substrate specificity of the $L$. pentosus $\beta$-galactosidase for various structurally related substrates $p$-nitrophenyl- $\beta$-D-mannopyranoside, $p$-nitrophenyl- $\beta$-D- 
xylopyranoside, $\quad$-nitrophenyl- $\beta$-D-glucopyranoside and $\quad p$-nitrophenyl- $\beta$-Dcellobioside were used. Activities were determined in accordance to standard oNPG assay conditions using the respective substrate in concentrations of $22 \mathrm{mM}$.

\subsection{Transgalactosylation activity}

Purified $\beta$-galactosidase from $L$. pentosus ( $5 U_{o N P G}$ per $\mathrm{mL}$ reaction mixture) was used for the discontinuous formation of galacto-oligosaccharides (GOS) at $30^{\circ} \mathrm{C}$ using $205 \mathrm{~g} / \mathrm{L}$ of lactose in $50 \mathrm{mM}$ sodium phosphate buffer $(\mathrm{pH} 6.5,2 \mathrm{mM} \mathrm{MgCl}$ ) as substrate. Samples were taken at various intervals and the composition of the GOS mixture was analyzed by capillary electrophoresis (CE) and high-performance anion exchange chromatography with pulsed amperometric detection (HPAEC-PAD) as described previously [13].

\section{Results}

\subsection{Formation and purification of $\beta$-galactosidase from $L$. pentosus}

L. pentosus KUB-ST10-1 was selected for detailed studies on its $\beta$-galactosidase since this strain grew very well on lactose, it showed high $\beta$-gal activity in a screening, in which several lactic acid bacteria were compared pertaining to their ability to form this enzyme activity (data not shown), and since its $\beta$-galactosidase

185 had not been studied in any detail previously. Batch cultivations of $L$. pentosus were carried out in a $10-\mathrm{L}$ laboratory fermenter at $37^{\circ} \mathrm{C}$ without $\mathrm{pH}$ control using lactosebased MRS medium. The biomass was harvested after $18 \mathrm{~h}$ of growth when $\beta$-gal activity reached a maximum of 644 units $\left(\mathrm{U}_{\mathrm{ONPG}}\right)$ per litre fermentation broth. $\beta$ Galactosidase was purified to apparent homogeneity from the crude cell extract using

190 a two-step purification protocol based on hydrophobic interaction and affinity 
chromatography. The enzyme was purified 16 -fold to a specific activity of $97 \mathrm{U} / \mathrm{mg}$ of protein, using standard assay conditions with oNPG as the substrate.

\subsection{Properties of $\beta$-galactosidase from $L$. pentosus}

L. pentosus $\beta$-galactosidase is a heterodimer $\left(M_{r} \sim 107 \mathrm{kDa}\right)$ consisting of a small 195 ( 35 kDa) and large ( 72 kDa) subunit as judged by SDS-PAGE (Figure 1A) and native PAGE (Figure 1B). The additional protein band ( $80 \mathrm{kDa})$ in native PAGE when staining with Coomassie Blue presumably results from degradation of the intact 107-kDa enzyme, as was previously shown for the related $\beta$-gal from $L$. reuteri by using mass spectrometry [9]. Active staining on native PAGE with MUG yielded only 200 one band with $\beta$-galactosidase activity, corresponding to the larger band in Figure 1B. Active staining on the SDS-PAGE gel after treating the enzyme in SDS buffer at $60^{\circ} \mathrm{C}$ for $5 \mathrm{~min}$, thus separating the two subunits without unfolding, showed that one band corresponding to the large subunit exhibited activity with MUG (not shown). In contrast, the small subunit by itself did not show any activity. When the enzyme was 205 treated in SDS buffer at $\sim 100^{\circ} \mathrm{C}$ for $5 \mathrm{~min}$, no activity could be detected after active staining on the gel.

\subsection{Substrate specificity}

To study the substrate specificity of $L$. pentosus $\beta$-galactosidase various structurally related artificial substrates were tested under standard assay conditions and 210 compared to oNPG. No appreciable activity was detected when using p-nitrophenyl$\beta$-D-xylopyranoside, $\quad$ o-nitrophenyl- $\beta$-D-glucopyranoside, $\quad p$-nitrophenyl- $\beta$-Dmannopyranoside and $p$-nitrophenyl- $\beta$-D-cellobioside as substrates for the activity assay.

\subsection{Enzyme kinetics}


215 Steady-state kinetic studies were performed with the preferred substrates lactose and $o N P G$ and the kinetic constants $\mathrm{K}_{\mathrm{m}}, \mathrm{v}_{\mathrm{max}}$, and $\mathrm{k}_{\mathrm{cat}}$ were determined. The $\mathrm{k}_{\mathrm{cat}}$ values were calculated on the basis of theoretical $v_{\max }$ values obtained by nonlinear regression using SigmaPlot. Data are summarized in Table 1. The catalytic efficiencies $\left(\mathrm{K}_{\mathrm{cat}} / \mathrm{K}_{\mathrm{m}}\right)$ for the two substrates, oNPG and lactose, indicate that $o N P G$ is 220 the preferred substrate in accordance with other microbial $\beta$-galactosidases.

\subsection{Effects of $\mathrm{pH}$ and temperature}

The $\mathrm{pH}$ optimum of $L$. pentosus $\beta$-galactosidase activity is $\mathrm{pH} 8.0$ and $\mathrm{pH} 7.5$ in glycine buffer when using lactose and oNPG as substrate, respectively (Figure 2). In general, the enzyme is more active in the alkaline range $(\mathrm{pH} 7.0-8.5)$, and it showed 225 a pronounced effect of the buffer system used on activity. The effect of different buffers and $\mathrm{pH}$ values on stability was investigated subsequently in more detail. Catalytic or kinetic stability, i.e., the length of time an enzyme remains active before undergoing irreversible inactivation, was measured for various $\mathrm{pH}$ values at a constant temperature of $37^{\circ} \mathrm{C}$, and the inactivation constants $\left(k_{\text {in }}\right)$ and the half-life

230 times of denaturation $\left(\tau_{1 / 2}\right)$ were determined (Table 2$) \cdot \beta$-Galactosidase showed firstorder inactivation kinetics at all $\mathrm{pH}$ values studied when analysed in the $\ln$ (residual activity) versus time plot (not shown). Highest $\tau_{1 / 2}$ values were calculated in glycine buffer ( $\mathrm{pH} 8.0$ and 8.5 ) where the stability was increased up to 3.2-fold compared to when using sodium phosphate buffer at $\mathrm{pH}$ 6.5. Highest inactivation constants and 235 hence least stabilities were obtained in sodium acetate buffer $(\mathrm{pH} 4.0$ and 5.0) and glycine buffer ( $\mathrm{pH} 9.0)$, with $\tau_{1 / 2}$ values of less than $1.5 \mathrm{~h}$.

The optimum temperature measured under standard assay conditions (10 $\mathrm{min}$ ) for lactose and $o N P G$ hydrolysis was $60-65^{\circ} \mathrm{C}$ and $55^{\circ} \mathrm{C}$, respectively (Figure 3). The effect of temperature on stability of $\beta$-galactosidase from $L$. pentosus was 
240 investigated at the $\mathrm{pH}$ value of milk, $\mathrm{pH} \mathrm{6.5,} \mathrm{both} \mathrm{in} \mathrm{the} \mathrm{absence} \mathrm{and} \mathrm{presence} \mathrm{of} 2$ $\mathrm{mM} \mathrm{MgCl}$. Inactivation constants and half-life times were calculated as described above. The addition of $2 \mathrm{mM} \mathrm{MgCl} 2$ to the buffer improved stability significantly, increasing the half life times $\tau_{1 / 2}$ of the enzyme at 30,37 and $42^{\circ} \mathrm{C} 3.2-, 4.9$ - and 5.6fold, respectively (Table 3; Figure 4).

\section{$245 \quad 3.6$ Transgalactosylation activity}

In order to assess the potential of the novel $\beta$-galactosidase from $L$. pentoses for the production of GOS, a discontinuous lactose conversion process was studied at $30^{\circ} \mathrm{C}$, using an initial lactose concentration of $205 \mathrm{~g} / \mathrm{L}$ in $50 \mathrm{mM}$ sodium phosphate buffer (+ $2 \mathrm{mM} \mathrm{MgCl} 2, \mathrm{pH} 6.5$ ) and $5 \mathrm{U}_{\mathrm{ONPG}} / \mathrm{mL}$ of $\beta$-galactosidase activity to produce GOS.

250 The maximum GOS yield (31\%) was obtained at a lactose conversion of $78 \%$ (Figure 5). The newly formed sugar mixture contained $31.5 \%$ glucose, $15.9 \%$ galactose, $21.9 \%$ lactose, $11.4 \%$ non-lactose disaccharides, $18.7 \%$ trisaccharides and $0.6 \%$ tetrasaccharides as analysed by capillary electrophoresis and highperformance anion exchange chromatography with pulsed amperometric detection, 255 and using authentic sugars and the standard addition technique for comparison. The main GOS products identified were non-lactose disaccharides mainly of the $\beta-(1 \rightarrow 3)$

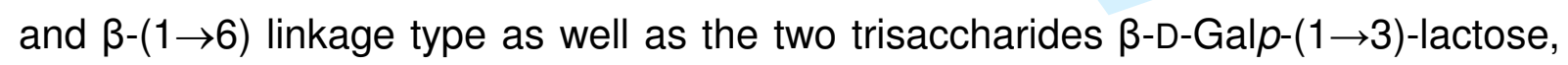

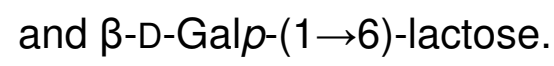

\section{Discussion}

The genus Lactobacillus is the largest among the Lactobacteriaceae and includes more than a hundred described species [29]. Lactobacilli are nutritionally fastidious, metabolize a varying range of different carbohydrates, and are associated with a large variety of animals and plants. They are extensively used for fermentations of 
265 dairy products, meat, fish and plant material such as vegetables, and thus have been investigated intensively for their industrial applications [30]. Lactose utilisation is a primary function of lactobacilli and other LAB used in the fermentation of milk. The mechanism by which lactose is transported into the cell determines largely the subsequent pathway for the hydrolysis of this disaccharide. In several Lactobacillus 270 species lactose is transported via phosphotransferase systems, which results in phosphorylation of lactose concomitant with its uptake. The resulting lactose-6'phosphate is then hydrolysed by phospho- $\beta$-galactosidase. Alternatively, lactose is taken up by secondary transport systems, and lactose is further metabolised by $\beta$ galactosidase within the cell [31,32]. While the organisation of these lactose genes,

275 which are often forming operons or operon-like structures with modular organisation, has been studied in much detail, the properties of some of the enzymes encoded by the genes organised in these operons, including $\beta$-galactosidases, have received significantly less attention. It is thus surprising that $\beta$-galactosidases from lactobacilli, which play an eminent role in the metabolism of the principal carbohydrate in milk, 280 have only been characterised in detail pertaining to their physical and biochemical properties in a few instances, and little attention has been paid to the catalytic ability of these enzymes with respect to their transglycosylation reactions [12, 17, 33].

Recently, we reported on the comprehensive characterisation of the $\beta$-galactosidases from $L$. reuteri and L. acidophilus, and pointed out their applicability for the 285 biocatalytic production of GOS [9, 13, 34, 35]. In this paper, we present the detailed biochemical characterisation and the transgalactosylation activity of a novel $\beta$ galactosidase from $L$. pentosus. The strain KUB-ST10-1 used throughout this research was isolated from a soil sample in Thailand, and was selected for further characterisation based on a screening and its high $\beta$-galactosidase activity when 290 grown on lactose. It was of interest to determine whether a $\beta$-galactosidase from a 
source other than those traditionally used in the dairy industry may have unique properties or characteristics. In a recent phylogenetic analysis based on 16S rRNA genes the genus Lactobacillus was grouped into five major divisions [36]. In this grouping, $L$. acidophilus belongs to group $A$ and $L$. reuteri to group $B$, while $L$. 295 pentosus is a member of group $C$ [36], hence might differ in its metabolic activities from the sources of $\beta$-galactosidases recently characterised in our group.

The structural features of $\beta$-galactosidases from lactobacilli are varying to a great extent. While heterodimeric structures are in general less frequently encountered among microbial $\beta$-galactosidases, these seem to prevail among Lactobacillus $\beta$ 300 galactosidases. Lactobacillal heterodimeric $\beta$-galactosidases are encoded by two genes, lacL and lacM, and have been described in e.g., L. acidophilus [34, 37], L. coryniformis [38], L. helveticus [39], L. johnsonii [40], L. plantarum [41], L. reuteri [9] and L. sakei [42]. These $\beta$-galactosidases of the LacLM type have been classified as members of glycoside family $\mathrm{GH} 2$ in the CAZy (Carbohydrate-Active Enzymes)

305 databank (http://www.cazy.org). In contrast to this, $\beta$-galactosidase from L. salivarius was reported to be a monomer of ca. $30 \mathrm{kDa}$ [43], the enzyme from L. delbrueckii subsp. bulgaricus a homodimer of $220 \mathrm{kDa}$ [44], $\beta$-galactosidase from L. helveticus a homotetramer of $257 \mathrm{kDa}$ [45], and L. plantarum forms - in addition to the above mentioned heterodimeric enzyme - a homohexameric $\beta$-galactosidase of ca. 325

$310 \mathrm{kDa}$ [46]. Some of these later $\beta$-galactosidases are members of glycoside family GH42. $\beta$-Galactosidase from L. pentosus KUB-ST10-1 is a heterodimer consisting of two subunits of approximately 35 and $72 \mathrm{kDa}$, which is in agreement with the majority of lactobacillal $\beta$-galactosidases reported hitherto, and is thus also of the LacLM type. The steady-state kinetic constants for $\beta$-galactosidase from $L$. pentosus were 315 determined for the artificial chromogenic substrate oNPG and the natural substrate lactose. The $\mathrm{k}_{\text {cat }} / \mathrm{K}_{\mathrm{m}}$ value for oNPG is significantly higher than that of lactose, 
indicating oNPG as the better substrate. The $\mathrm{K}_{\mathrm{m}}$ value of $37.8 \mathrm{mM}$ determined for lactose compares positively with the Michaelis constants reported for commercially employed $\beta$-galactosidases, e.g., from Aspergillus niger (54-100 mM), A. oryzae 320 (36-180 mM), Kluyveromyces fragilis (15-52 mM) [47] and Kluyveromyces lactis (20 $\mathrm{mM}$ ) [48]. This value is, however, somewhat higher than the values reported for other Lactobacillus $\beta$-galactosidases: 13 mM for $\beta$-gal from L. reuteri L103 [9], $1.27 \mathrm{mM}$ for $\beta$-gal from L. kefiranofaciens [49], and $4.04 \mathrm{mM}$ for $\beta$-gal from L. acidophilus [34]. The higher $\mathrm{K}_{\mathrm{m} \text {,lactose }}$ value for $L$. pentosus $\beta$-gal as compared to other lactobacillal 325 enzymes, especially those of milk origin, could indicate a lesser adaptation of this soil-isolated strain to lactose utilization. L. pentosus $\beta$-gal is rather specific for the $\beta$ $(1 \rightarrow 4)$ galactosyl linkage. When using a range of structurally related nitrophenyl substrates, essentially no activity was measured for the $\beta$-(1 $\rightarrow 4)$ linked D-glucoside, D-mannoside, and D-xyloside substrates.

330 L. pentosus $\beta$-galactosidase is optimally active at $\mathrm{pH} 7.5$ (glycine buffer) and $55^{\circ} \mathrm{C}$ when using oNPG as substrate, and $\mathrm{pH} 8.0$ (glycine buffer) and $60-65^{\circ} \mathrm{C}$ when lactose was used as substrate under otherwise standard activity assay conditions (10-min assay). This $\mathrm{pH}$ optimum is slightly more alkaline than reported for most other lactobacillal $\beta$-galactosidases, which show an optimum of $6.5-7.0[9,34]$, 335 however, we observed a pronounced effect of the buffer system used on the optimal $\mathrm{pH}$, and that certainly affects the actual value determined. The temperature optimum of $L$. pentosus $\beta$-gal of $60-65^{\circ} \mathrm{C}$ is considerably higher than reported for most other $\beta$-galactosidases from lactobacilli, which typically are optimally active in the range of $45-50^{\circ} \mathrm{C}[9,34,43,50]$. L. pentosus KUB-ST10-1 can grow at temperatures of up to $34045^{\circ} \mathrm{C}$. This is higher than typical growth temperatures observed for many Lactobacillus spp. The increased temperature optimum and stability of the $L$. pentosus $\beta$-galactosidase might reflect an adaptation to these higher growth 
temperatures. Because of this increased temperature optimum we investigated the thermostability of $L$. pentosus $\beta$-gal in more detail, determining the inactivation

345 kinetics at different conditions. With respect to $\mathrm{pH}$, highest half-life times $\tau_{1 / 2}$ were obtained in glycine buffer at $\mathrm{pH} 8.0-8.5$ and at $37^{\circ} \mathrm{C}(43-47 \mathrm{~h})$. Again, the buffer system had a pronounced effect on stability, since the inactivation constants $k_{\text {in }}$ determined were approximately twice as high at $\mathrm{pH} 7.5$ when using sodium phosphate instead of glycine buffer; however the use of glycine buffer might be

350 impractical for technical applications. When using the former buffer, highest stability was observed at $\mathrm{pH} 6.5-7.0$ with $\tau_{1 / 2}$ of $14.6 \mathrm{~h}$. Addition of $2 \mathrm{mM} \mathrm{Mg}^{2+}$ increased stability and hence $\tau_{1 / 2}$ of $\beta$-gal activity significantly by a factor of up to 5.6 -fold. For example, $\tau_{1 / 2}$ values of e.g. $\sim 75 \mathrm{~h}$ were obtained at $\mathrm{pH} 6.5,37^{\circ} \mathrm{C}$ and when using phosphate buffer containing $2 \mathrm{mM}$ of $\mathrm{Mg}^{2+}$. This increase in stability and activity of $L$.

355 pentosus $\beta$-gal could be a considerable advantage when using technical substrates such as cheese whey or whey permeates for the production of GOS, since cheese whey contains approximately $1.5 \mathrm{mM}$ of $\mathrm{Mg}^{2+}$. Thus, use of these technical substrates could improve the performance of $L$. pentosus $\beta$-gal without the need of adding exogenous $\mathrm{Mg}^{2+}$.

$360 \beta$-Galactosidases have recently attained significant interest in biocatalytic processes towards the synthesis of oligosaccharides or various galactosylated compounds; for this purpose various galactosides can serve as galactosyl donor. Especially galactooligosaccharides (GOS), which are formed from lactose as a result of transgalactosylation, have attracted renewed attention in the field of functional food 365 because of their proven benefits on health [16, 17, 18, 20]. As GOS are only transiently formed and are in turn substrates for the $\beta$-galactosidase as well, a maximum GOS yield of $31 \%(\mathrm{w} / \mathrm{v})$ was reached at $78 \%$ lactose conversion when using the $\beta$-gal of $L$. pentosus. The main GOS spectrum formed from lactose by this 


\section{1}

enzyme is very similar to those found for $\beta$-gal from $L$. reuteri [13] and $L$. acidophilus

[34]. L. pentosus $\beta$-gal shows a high specificity for the formation of $\beta-(1 \rightarrow 6)$ and $\beta$ $(1 \rightarrow 3)$ linkages, and hence the main transgalactosylation products detected were the

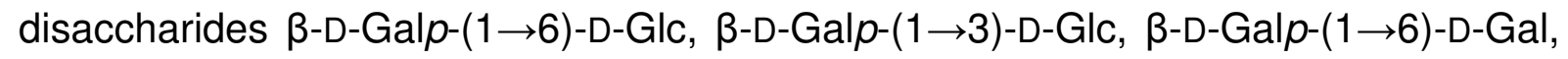

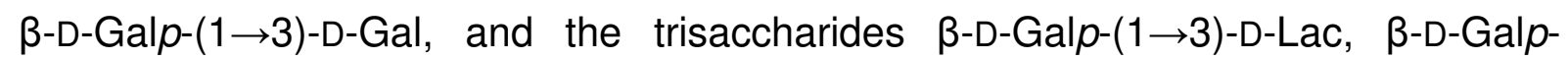
$(1 \rightarrow 6)$-D-Lac. In a recent study a strong prebiotic effect was attributed to some of 375 these compounds [51], and hence it is likely that the GOS mixture formed by $L$. pentosus $\beta$-gal has a considerable potential as prebiotic.

In conclusion, this work presented the characterisation and transgalactosylation capacity of a novel $\beta$-galactosidase from $L$. pentosus. Although the $\beta$-galactosidase described here is not derived from a proven probiotic Lactobacillus strain, the physical and biochemical characteristics are quite similar to those derived from probiotic strains $[9,34]$ with the exception that it is considerably more stable at higher temperatures. Also the GOS spectrum and yields are comparable with the former studies, making this novel enzyme that is produced by a well-known food-grade organism interesting for potential applications in food industry.

Acknowledgements This research work was supported financially by the Research Centre Applied Biocatalysis (Graz, Austria) and the National Research Council of Thailand (to MY). OJ thanks the Duo-Thailand 2008 program for a mobility grant. The authors have declared no conflict of interest. 


\section{References}

[1] Zanoni, P., Farrow, J. A. E., Phillips, B. A., Collins, M. D., Lactobacillus pentosus (Fred, Peterson and Anderson) sp. nov., nom. rev. Int. J. Syst. Bacteriol. 1987, 37, 339-341.

[2] Wynne, A. G., Gibson, G. R., Brostoff, J., Composition comprising a Lactobacillus pentosus strain and uses thereof. United States Patent 7125708, 10/24/2006, 2006.

[3] Kim, H.-J., Shin, H.-S., Ha, W.-K., Yang, H.-J., Lee, S.-W., Characterization of lactic bacterial strains isolated from raw milk. Asian Austral. J. Anim. 2006, 19, 131-136.

400 [4] Fred, E. B., Peterson, W. H., Anderson, A.J., The characteristics of certain pentose-destroying bacteria, especially as concerns their action on arabinose and xylose. J. Biol. Chem. 1921, 48, 385-412.

[5] Møller, P. L., Jørgensen, F., Hansen, O. C., Madsen, S. M., Stougaard, P., Intra- and extracellular $\beta$-galactosidases from Bifidobacterium bifidum and $B$. 405 infantis: molecular cloning, heterologous expression, and comparative characterization. Appl. Environ. Microbiol. 2001, 67, 2276-2283.

[6] Coombs, J. M., Brenchley, J. E., Biochemical and phylogenetic analyses of a cold-active $\beta$-galactosidase from the lactic acid bacterium Carnobacterium piscicola BA. Appl. Environ. Microbiol. 1999, 65, 5443-5450.

410 [7] Nguyen, T.-H., Splechtna, B., Yamabhai, M., Haltrich, D., Peterbauer, C., Cloning and expression of the $\beta$-galactosidase genes from Lactobacillus reuteri in Escherichia coli. J. Biotechnol. 2007, 129, 581-591.

[8] Schmidt, B. F., Adams, R. M., Requadt, C., Power, S., Mainzer, S. E., Expression and nucleotide sequence of the Lactobacillus bulgaricus $\beta$ - 
415 galactosidase gene cloned in Escherichia coli. J. Bacteriol. 1989, 171, 625635.

[9] Nguyen, T.-H., Splechtna, B., Steinböck, M., Kneifel, W., et al., Purification and characterization of two novel $\beta$-galactosidases from Lactobacillus reuteri. J. Agric. Food Chem. 2006, 54, 4989-4998.

420 [10] David, S., Stevens, H., van Riel, M., Simons, G., de Vos, W. M., Leuconostoc lactis $\beta$-galactosidase is encoded by two overlapping genes. J. Bacteriol. 1992, 174, 4475-4481.

[11] Toba, T., Tomita, Y., Itoh, T., Adachi, S., $\beta$-Galactosidase of lactic acid bacteria: Characterization by oligosaccharides formed during hydrolysis of 425 lactose. J. Dairy Sci. 1981, 64, 185-192.

[12] Garman, J., Coolbear, T., Smart, J., The effect of cations on the hydrolysis of lactose and the transferase reactions catalysed by $\beta$-galactosidase from six strains of lactic acid bacteria. Appl. Microbiol. Biotechnol. 1996, 46, 22-27.

[13] Splechtna, B., Nguyen, T.-H., Steinböck, M., Kulbe, K. D., et al., Production of 430 prebiotic galacto-oligosaccharides from lactose using $\beta$-galactosidases from Lactobacillus reuteri. J. Agric. Food Chem. 2006, 54, 4999-5006.

[14] Rastall, R. A., Maitin, V., Prebiotics and synbiotics: towards the next generation. Curr. Opin. Biotechnol. 2002, 13, 490-496.

[15] Gibson, G. R., Probert, H. M., Loo, J. V., Rastall, R. A., Roberfroid, M. B., 435 Dietary modulation of the human colonic microbiota: updating the concept of prebiotics. Nutr. Res. Rev. 2004, 17, 259-275.

[16] Macfarlane, G. T., Steed, H., Macfarlane, S., Bacterial metabolism and healthrelated effects of galacto-oligosaccharides and other prebiotics. J. Appl. Microbiol. 2008, 104, 305-344. 
440 [17] Park, A. R., Oh, D. K., Galacto-oligosaccharide production using microbial $\beta$ galactosidase: current state and perspectives. Appl. Microbiol. Biotechnol. 2010, 85, 1279-1286.

[18] Gosling, A., Stevens, G. W., Barber, A. R., Kentish, S. E., Gras, S. L., Recent advances refining galactooligosaccharide production from lactose. Food $445 \quad$ Chem. 2010, 121, 307-318.

[19] Zarate, S., Lopez-Leiva, M. H., Oligosaccharide formation during enzymatic lactose hydrolysis: A literature review. J. Food Prot. 1990, 53, 262-268.

[20] Nakayama, T., Amachi, T., $\beta$-Galactosidase, enzymology, in: Flickinger, M. C., Drew, S.W. (Eds.) Encyclopedia of Bioprocess Technology: Fermentation, 450 Biocatalysis, and Bioseparation, John Wiley and Sons, New York, 1999; Vol. 3, pp. 1291-1305.

[21] Sako, T., Matsumoto, K., Tanaka, R., Recent progress on research and application of non-digestible galacto-oligosaccharides. Int. Dairy J. 1999, 9, 69-80.

455 [22] Rabiu, B. A., Jay, A. J., Gibson, G. R., Rastall, R. A., Synthesis and fermentation properties of novel galacto-oligosaccharides by $\beta$-galactosidases from Bifidobacterium species. Appl. Environ. Microbiol. 2001, 67, 2526-2530.

[23] Tzortzis, G., Goulas, A. K., Gee, J. M., Gibson, G. R., A novel galactooligosaccharide mixture increases the bifidobacterial population numbers in a 460 continuous in vitro fermentation system and in the proximal colonic contents of pigs in vivo. J. Nutr. 2005, 135, 1726-1731.

[24] Nonaka, Y., Izumo, T., Izumi, F., Maekawa, T. et al., Antiallergic effects of Lactobacillus pentosus strain S-PT84 mediated by modulation of Th1/Th2 immunobalance and induction of IL-10 production. Int. Arch. Allergy Immunol. 2008, 145, 249-257. 
[27] Bradford, M. M., A rapid and sensitive method for the quantitation of microgram quantities of protein utilizing the principle of protein dye binding. Anal. Biochem. 1976, 72, 248-254.

[28] Laemmli, U.K., Cleavage of structural proteins during the assembly of the head of bacteriophage T4. Nature 1970, 227, 680-685.

[29] Felis, G. E., Dellaglio, F., Taxonomy of lactobacilli and bifidobacteria. Curr. Issues Intest. Microbiol. 2007, 8, 44-61.

[30] Konings, W. N., Kok, J., Kuipers, O. P., Poolman, B., Lactic acid bacteria: the bugs of the new millennium. Curr. Opin. Microbiol. 2000, 3, 276-282.

[31] de Vos, W. M., Vaughan, E. E., Genetics of lactose utilization in lactic acid bacteria. FEMS Microbiol. Rev. 1994, 15, 217-237.

485 [32] Honda, H., Kataoka, F., Nagaoka, S., Kawai, Y. et al., $\beta$-Galactosidase, phospho- $\beta$-galactosidase and phospho- $\beta$-glucosidase activities in lactobacilli strains isolated from human faeces. Lett. Appl. Microbiol. 2007, 45, 461-466.

[33] Vasiljevic, T., Jelen, T., Oligosaccharide production and proteolysis during lactose hydrolysis using crude cellular extracts from lactic acid bacteria. Le Lait 2003, 83, 453-467. 
[34] Nguyen, T.-H., Splechtna, B., Krasteva, S., Kneifel, W. et al., Characterization and molecular cloning of a heterodimeric $\beta$-galactosidase from the probiotic strain Lactobacillus acidophilus R22. FEMS Microbiol. Lett. 2007, 269, 136144.

495 [35] Splechtna, B., Nguyen, T.-H., Zehetner, R., Lettner, H. P. et al., Process development for the production of prebiotic galacto-oligosaccharides from lactose using $\beta$-galactosidase from Lactobacillus sp. Biotechnol. J. 2007, 2, 480-485.

[36] Canchaya, C., Claesson, M. J., Fitzgerald, G.F., van Sinderen, D., O'Toole, P. 500 W., Diversity of the genus Lactobacillus revealed by comparative genomics of five species. Microbiology 2006, 152, 3185-3196.

[37] Halbmayr, E., Mathiesen, G., Nguyen, T.-H., Maischberger, T. et al. High-level expression of recombinant $\beta$-galactosidases in Lactobacillus plantarum and Lactobacillus sakei using a Sakacin P-based expression system. J. Agric. Food Chem. 2008, 56, 4710-4719.

[38] Corral, J. M., Banuelos, O., Adrio, J. L., Velasco, J., Cloning and characterization of a $\beta$-galactosidase encoding region in Lactobacillus coryniformis CECT 5711. Appl. Microbiol. Biotechnol. 2006, 73, 640-646.

[39] Fortina, M. G., Ricci, G., Mora, D., Guglielmetti, S., Manichini, P. L., Unusual 510 organization for lactose and galactose gene clusters in Lactobacillus helveticus. Appl. Environ. Microbiol. 2003, 69, 3238-3243.

[40] Pridmore, R. D., Berger, B., Desiere, F., Vilanova, D. et al., The genome sequence of the probiotic intestinal bacterium Lactobacillus johnsonii NCC 533. Proc. Natl. Acad. Sci. U. S. A. 2004, 101, 2512-2517. 
515 [41] Kleerebezem, M., Boekhorst, J., van Kranenburg, R., Molenaar, D. et al., Complete genome sequence of Lactobacillus plantarum WCFS1. Proc. Natl. Acad. Sci. U. S. A. 2003, 100, 1990-1995.

[42] Obst, M., Meding, E. R., Vogel, R. F., Hammes, W. P., Two genes encoding the $\beta$-galactosidase of Lactobacillus sake. Microbiology 1995, 141, 3059-3066.

520 [43] Bae, H. C., Choi, J. W., Nam, M. S., Purification and characterisation of $\beta-$ galactosidase from Lactobacillus salivarius subsp. salivarius Nam27. Korean J. Food Sci. Ani. Resour. 2007, 27, 110-116.

[44] Adams, R. M., Yoast, S., Mainzer, S. E., Moon, K. et al., Characterization of two cold-sensitive mutants of the $\beta$-galactosidase from Lactobacillus delbruckii subsp. bulgaricus. J. Biol. Chem. 1994, 269, 5666-5672.

[45] de Macias, M. E., Manca de Nadra, M. C., Strasser de Saad, A. M., Pesce de Ruiz Holgado, A. A., Oliver, G., Isolation and properties of $\beta$-galactosidase of a strain of Lactobacillus helveticus isolated from natural whey starter. J. Appl. Biochem. 1983, 5, 275-281.

530 [46] Acebron, I., Curiel, J. A., de Las Rivas, B., Munoz, R., Mancheno, J. M., Cloning, production, purification and preliminary crystallographic analysis of a glycosidase from the food lactic acid bacterium Lactobacillus plantarum CECT 748(T). Protein Expr. Purif. 2009, 68, 177-182.

[47] de Roos, A., Industrial enzymes: enzymes in dairy applications, in: Aehle, W. (Ed.), Enzymes in Industry, Wiley-VCH, Weinheim 2004, Vol. 2, p. 144.

[48] Kim, C. S., Ji, E. S., Oh, D. K. Expression and characterization of Kluyveromyces lactis $\beta$-galactosidase in Escherichia coli. Biotechnol. Lett. 2003, 25, 1769-1774. 
[49] Itho, K., Toba, T., Itho, T., Adachi, S., Properties of $\beta$-galactosidase of Lactobacillus kefiranofaciens $\mathrm{K}-1$ isolated from kefir grains. Lett. Appl. Microbiol. 1992, 15, 232-234.

[50] Ito, M., Deguchi, Y., Miyamori, A., Matsumoto, K. et al., Effects of administration of galacto-oligosaccharides on the human faecal microflora, stool weight and abdominal sensation. Microb. Ecol. Health. D 1990, 3, 285292.

[53] Sanz, M. L., Cote, G. L., Gibson, G. R., Rastall, R. A., Influence of glycosidic linkages and molecular weight on the fermentation of maltose-based oligosaccharides by human gut bacteria. J. Agric. Food Chem. 2006, 54, 9779-9784 


\section{$550 \quad \underline{\text { Tables }}$}

Table 1. Kinetic properties of $\beta$-galactosidase from Lactobacillus pentosus for the hydrolysis of lactose and $o$-nitrophenyl- $\beta$-D-galactopyranoside (oNPG)

\begin{tabular}{|c|c|c|c|}
\hline substrate & $\begin{array}{l}\text { method for } \\
\text { determination of } \\
\text { enzyme activity }\end{array}$ & kinetic parameter & $\begin{array}{l}\text { L. pentosus } \\
\beta \text {-galactosidase }\end{array}$ \\
\hline \multirow[t]{4}{*}{ lactose } & release of D-glucose & $\mathrm{v}_{\max }\left(\mu \mathrm{mol} \mathrm{min}^{-1} \mathrm{mg}^{-1}\right)$ & $11.3 \pm 0.75$ \\
\hline & & $\mathrm{K}_{\mathrm{m}}(\mathrm{mM})$ & $37.8 \pm 9.41$ \\
\hline & & $\mathrm{k}_{\text {cat }}\left(\mathrm{s}^{-1}\right)$ & 20.1 \\
\hline & & $\mathrm{k}_{\mathrm{cat}} / \mathrm{K}_{\mathrm{m}}\left(\mathrm{mM}^{-1} \mathrm{~s}^{-1}\right)$ & 0.532 \\
\hline \multirow[t]{4}{*}{ oNPG } & release of $o \mathrm{NP}$ & $v_{\max }\left(\mu \mathrm{mol} \mathrm{min}^{-1} \mathrm{mg}^{-1}\right)$ & $304 \pm 24.6$ \\
\hline & & $\mathrm{K}_{\mathrm{m}}(\mathrm{mM})$ & $1.67 \pm 0.64$ \\
\hline & & $\mathrm{k}_{\mathrm{cat}}\left(\mathrm{s}^{-1}\right)$ & 543 \\
\hline & & $\mathrm{k}_{\mathrm{cat}} / \mathrm{K}_{\mathrm{m}}\left(\mathrm{mM}^{-1} \mathrm{~s}^{-1}\right)$ & 325 \\
\hline
\end{tabular}


Table 2. Kinetic stability of $\beta$-galactosidase from Lactobacillus pentosus at various $\mathrm{pH}$ values at $37^{\circ} \mathrm{C}$.

\begin{tabular}{llcc}
\hline Buffer & $\mathrm{pH}$ & Inactivation constant $k_{\text {in }}\left(\mathrm{h}^{-1}\right)$ & Half-life $r_{1 / 2}(\mathrm{~h})$ \\
\hline sodium acetate & 4.0 & $3770 \times 10^{-3}$ & 0.18 \\
sodium acetate & 5.0 & $504 \times 10^{-3}$ & 1.37 \\
sodium acetate & 5.5 & $131 \times 10^{-3}$ & 5.31 \\
sodium acetate & 6.0 & $91.9 \times 10^{-3}$ & 7.54 \\
sodium phosphate & 6.0 & $63.3 \times 10^{-3}$ & 10.9 \\
sodium phosphate & 6.5 & $47.6 \times 10^{-3}$ & 14.6 \\
sodium phosphate & 7.0 & $47.6 \times 10^{-3}$ & 14.6 \\
sodium phosphate & 7.5 & $95.8 \times 10^{-3}$ & 7.24 \\
glycine & 7.5 & $43.6 \times 10^{-3}$ & 15.9 \\
glycine & 8.0 & $14.7 \times 10^{-3}$ & 47.2 \\
glycine & 8.5 & $16.0 \times 10^{-3}$ & 43.3 \\
glycine & 9.0 & $1045 \times 10^{-3}$ & 0.66 \\
\hline
\end{tabular}


1

3

4

5

6
7

9

10

11

12

13

14

15

16

17

18

19

20

21

Table 3. Kinetic stability of $\beta$-galactosidase from Lactobacillus pentosus at various 560 temperatures with and without $\mathrm{MgCl}_{2}$ supplementation $(2 \mathrm{mM})$.

\begin{tabular}{|c|c|c|c|c|}
\hline & \multicolumn{2}{|c|}{ Sodium phosphate buffer (pH 6.5) } & \multicolumn{2}{|c|}{ Sodium phosphate buffer $\left(\mathrm{pH} 6.5,+\mathrm{Mg}^{2+}\right)$} \\
\hline $\begin{array}{c}\text { Temperature } \\
\left({ }^{\circ} \mathrm{C}\right)\end{array}$ & $\begin{array}{c}\text { Inactivation } \\
\text { constant } k_{\text {in }}\left(\mathrm{h}^{-1}\right)\end{array}$ & Half-life $r_{1 / 2}(\mathrm{~h})$ & $\begin{array}{c}\text { Inactivation } \\
\text { constant } k_{\text {in }}\left(\mathrm{h}^{-1}\right)\end{array}$ & Half-life $r_{1 / 2}(\mathrm{~h})$ \\
\hline 4 & $0.5 \times 10^{-3}$ & 1386 & nd & nd \\
\hline 23 & $0.8 \times 10^{-3}$ & 866 & nd & nd \\
\hline 30 & $9.0 \times 10^{-3}$ & 77.0 & $2.8 \times 10^{-3}$ & 248 \\
\hline 37 & $46.6 \times 10^{-3}$ & 14.9 & $9.4 \times 10^{-3}$ & 73.7 \\
\hline 42 & $212.7 \times 10^{-3}$ & 3.26 & $37.7 \times 10^{-3}$ & 18.4 \\
\hline
\end{tabular}




\section{Figure captions}

565 Figure 1. SDS-PAGE (A) and native PAGE (B) of purified $\beta$-galactosidase from $L$. pentosus. A: lane 1, molecular weight marker (Precision Plus Protein Dual Color, Biorad), CBB staining; lane 2, enzyme sample after treatment in SDS buffer at $100^{\circ} \mathrm{C}$ for 5 min, CBB staining. B: lane 1, molecular weight marker (High Molecular Weight Calibration Kit for electrophoresis, Amersham); lane 2, CBB staining.

570

Figure 2. $\mathrm{pH}$ optimum of $\beta$-galactosidase from $L$. pentosus using lactose $(\mathrm{A})$ and oNPG (B) as the substrate. Symbols: $\bullet$, sodium acetate buffer; $O$, sodium phosphate buffer; $\boldsymbol{\nabla}$, glycine buffer. Activities are given relative to standard assay conditions (sodium phosphate buffer, $\mathrm{pH} 6.5$ ).

Figure 3. Temperature optimum of $\beta$-galactosidase from $L$. pentosus when using lactose $(\bullet)$ and $o \mathrm{NPG}(\mathrm{O})$ as the substrate. Activities are given relative to standard assay conditions at $30^{\circ} \mathrm{C}$.

580 Figure 4. Inactivation kinetics of $\beta$-galactosidase from $L$. pentosus in sodium phosphate buffer ( $\mathrm{A} ; 50 \mathrm{mM}, \mathrm{pH} 6.5)$ and sodium phosphate buffer supplemented with $1 \mathrm{mM} \mathrm{MgSO}_{4}(\mathrm{~B} ; 50 \mathrm{mM}, \mathrm{pH}$ 6.5) at different temperatures.

Symbols: (A): $\bullet, 4^{\circ} \mathrm{C} ; \mathrm{O}, 23^{\circ} \mathrm{C} ; \boldsymbol{\nabla}, 30^{\circ} \mathrm{C} ; \nabla, 37^{\circ} \mathrm{C}$; $\mathbf{\square}, 42^{\circ} \mathrm{C}$; (B): $\bullet, 30^{\circ} \mathrm{C} ; \mathrm{O}, 37^{\circ} \mathrm{C}$; $\boldsymbol{\nabla}, 42^{\circ} \mathrm{C}$.

Figure 5. Formation of galacto-oligosaccharides (GOS) by $\beta$-galactosidase from $L$. pentosus during the discontinuous conversion reaction of $205 \mathrm{~g} / \mathrm{L}$ lactose in $50 \mathrm{mM}$ sodium phosphate buffer at $30^{\circ} \mathrm{C}$. (A) Formation of disaccharides $(\bullet)$, trisaccharides 
1

3

4

5

6

7

8

9

10

11

12

13

14

15

16

17

18

19

20

21

22

23

24

25

26

27

28

29

30

31

32

33

34

35

36

37

38

39

40

41

42

43

44

45

46

47

48

49

50

51

52

53

54

55

56

57

58

59

60

$(\mathrm{O})$, tetrasaccharides $(\boldsymbol{\nabla})$ and total GOS $(\nabla)$ during lactose conversion. (B) Time

590 course of reaction for lactose conversion; symbols: lactose $(\boldsymbol{\nabla})$, glucose $(\boldsymbol{\bullet})$, galactose (O). 


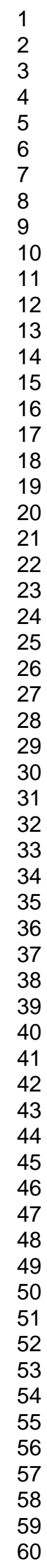

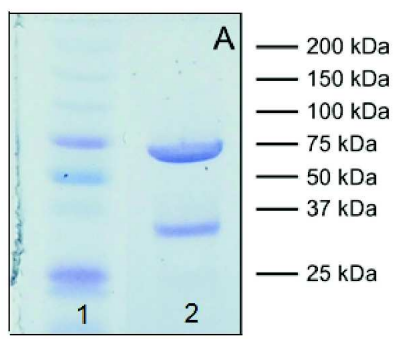

$210 \times 297 \mathrm{~mm}(600 \times 600 \mathrm{DPI})$

Wiley-VCH 


1
2
3
4
5
6
7
8
9
10
11
12
13
14
15
16
17
18
19
20
21
22
23
24
25
26
27
28
29
30
31
32
33
34
35
36
37
38
39
40
41
42
43
40
45
49
50
50
51
53
55
50

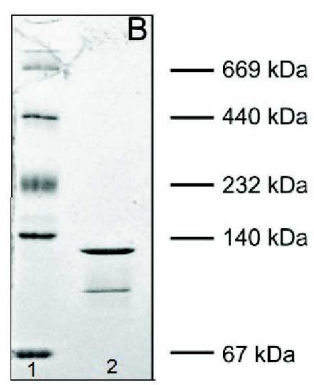

$210 \times 297 \mathrm{~mm}(600 \times 600 \mathrm{DPI})$

Wiley-VCH 